\title{
Variation of an indicator of Escherichia coli persistence from surface waters of mixed-use watersheds, and relationship with environmental factors
}

\author{
Emilie Lyautey ${ }^{1}$, Graham Wilkes ${ }^{2}$, Jim J. Miller ${ }^{3}$, Eric Van Bochove ${ }^{4}$, Hans Schreier ${ }^{5}$, \\ Wendell Koning ${ }^{6}$, Thomas A. Edge ${ }^{7}$, David R. Lapen ${ }^{2}$ and Edward Topp ${ }^{1 *}$ \\ 1 Agriculture and Agri-Food Canada, 1391 Sandford St, London, ON N5V 4T3, Canada \\ 2 Agriculture and Agri-Food Canada, 960 Carling Ave, Ottawa, ON K1A 0C6, Canada \\ 3 Agriculture and Agri-Food Canada, 5403 1st Ave S, Lethbridge, AB T1J 4B1, Canada \\ 4 Agriculture and Agri-Food Canada, 2560 boul. Hochelaga, Sainte-Foy, QC G1V 2J3, Canada \\ ${ }^{5}$ Institute for Resources, Environment and Sustainability, University of British Columbia, 429-2202 Main Mall, Vancouver, \\ BC V6T 1Z4, Canada \\ ${ }^{6}$ Alberta Environment, 2938-11 St. NE, Calgary, AB T2E 7L7, Canada \\ 7 Environment Canada, 867 Lakeshore Road, Burlington, ON L7R 4A6, Canada
}

Received 18 August 2009; Accepted 31 October 2010

\begin{abstract}
Escherichia coli is an indicator of fecal pollution used to mandate recreational and drinking water quality. Concentrations of culturable E. coli following contamination of surface water are determined by three factors: dilution; cell attachment to particulate material and settling or resuspension in the water column; and the net rate of change in viability. This study evaluated the variability in the latter parameter, and how predictive variation in death rate was of culturable population densities at the time of sampling. Water samples $(N=232)$ with varying levels of $E$. coli contamination were collected from 46 discrete locations in four watersheds across Canada over a three-month period and enumerated for culturable E. coli by membrane filtration plate counting $\left(\mathrm{T} 0_{\mathrm{EC}}\right)$. Water samples were again enumerated following a laboratory $24 \mathrm{~h}$ holding period at $30{ }^{\circ} \mathrm{C}$ in the dark, and the difference considered the death rate $\left(\Delta_{\mathrm{EC}}\right)$. Relationships of $\mathrm{T} 0_{\mathrm{EC}}$ and $\Delta_{\mathrm{EC}}$ with environmental and water chemistry factors were explored using step-wise multiple regression. The model predicting $\mathrm{T} 0_{\mathrm{EC}}$ indicated that stream order, total rainfall seven days in advance of sampling day, total phosphorus, and $\Delta_{\mathrm{EC}}$ were the most significant contributors. The model predicting $\Delta_{\mathrm{EC}}$ indicated that turbidity and $\mathrm{NH}_{3}+\mathrm{NH}_{4}$ were the most important contributors. A model suggests that the persistence factor is less important than dilution (i.e. stream order) in describing E. coli densities, followed by factors that influence the loading of $E$. coli into watersheds.
\end{abstract}

Key words: Escherichia coli / surface water / persistence / environmental factors

\section{Introduction}

Escherichia coli is ubiquitous in the gastrointestinal tracts of humans and other warm-blooded animals (Leclerc et al., 2001). In secondary habitats, such as water, the detection of $E$. coli is considered to be evidence of recent fecal contamination, and therefore an indicator of contamination with pathogenic microorganisms of human health concern (Dufour, 1984). E. coli serves as a basis on which the microbiological quality of recreational and drinking water is measured and mandated to minimize public health risks (USEPA, 2000).

\footnotetext{
*Corresponding author: Ed.Topp@agr.gc.ca
}

The concentration of $E$. coli in surface water at any one time will depend on the rate of fecal contaminant input, and on the rates of three processes that redistribute, remove, or augment culturable cell densities in the water, namely: (i) dilution; (ii) cell attachment to particulate material and subsequent settling or resuspension in the primary water column; and (iii) the net rate of change in viability due to cell death, or proliferation. Environmental factors that affect $E$. coli viability in natural waters include water temperature (Faust et al., 1975), predation (McCambridge and McMeekin, 1980), antibiotics (Carlucci and Pramer, 1960a), organic matter (Bouteleux et al., 2005), viral lysis (Carlucci and Pramer, 1960b), nutrients (Topp et al., 2003; 
Table 1. Watershed designation and location, number of sampling sites, number of samples collected, period of time covered by sampling, initial and final abundance of E. coli in samples, and abundance variation during laboratory holding period for each of the watershed sampled (Bras d'Henri (BDH), South Nation (SN), Oldman (OLD), and Sumas (SU)). Average, standard deviation (SD), minimum (min), and maximum ( $\max$ ) values are given for initial $\left(\mathrm{T} 0_{\mathrm{EC}}\right)$ and final $\left(\mathrm{T} 24_{\mathrm{EC}}\right)$ abundance in water $\left(\mathrm{CFU} .100 \mathrm{~mL}^{-1}\right)$, and for abundance variation $\left(\Delta_{\mathrm{EC}}(\%)\right)$.

\begin{tabular}{|c|c|c|c|c|}
\hline & $\mathrm{BDH}$ & $\mathrm{SN}$ & OLD & SU \\
\hline Province & Québec & Ontario & Alberta & British Columbia \\
\hline $\mathrm{N}^{\circ}$ sampling sites & 5 & 23 & 12 & 5 \\
\hline $\mathrm{N}^{\circ}$ samples & 19 & 134 & 63 & 20 \\
\hline $\begin{array}{l}\text { Sampling period } \\
(2007)\end{array}$ & 4-Jun to 30-Jul & 4-Jun to 13-Aug & 28-May to 13-Aug & 28-May to 7-Aug \\
\hline $\begin{array}{l}\mathrm{T}_{\mathrm{EC}} \text { (average } \pm \mathrm{SD} \\
[\mathrm{min}-\max ])\end{array}$ & $258 \pm 319[6-1090]$ & $282 \pm 700[1-6400]$ & $84 \pm 98[0-440]$ & $332 \pm 486$ [12-1770] \\
\hline $\begin{array}{l}\mathrm{T} 24_{\mathrm{EC}} \text { (average } \pm \mathrm{SD} \\
[\mathrm{min}-\mathrm{max}])\end{array}$ & $114 \pm 154[4-530]$ & $103 \pm 361[0-3900]$ & $34 \pm 37[0-154]$ & $152 \pm 167[7-670]$ \\
\hline $\begin{array}{l}\Delta_{\mathrm{EC}}(\text { average } \pm \mathrm{SD} \\
[\mathrm{min}-\mathrm{max}])\end{array}$ & $-48 \pm 37[-95$ to 50$]$ & $-58 \pm 49[-100$ to +250$]$ & $-39 \pm 83[-100$ to +413$]$ & $-29 \pm 49[-93$ to +77$]$ \\
\hline
\end{tabular}

Cook and Bolster, 2007), and irradiation with UV and visible light (Noble et al., 2004).

Given the widespread use of E. coli as an indicator of fecal contamination, understanding environmental conditions that influence the persistence of this microorganism in surface water is critical for improving our capacity to predict human health threats from waterborne disease. E. coli was originally thought to persist for only a limited time outside the gastrointestinal tract, where conditions differ drastically from the intestines of warm-blooded animals (Ishii and Sadowsky, 2008). However, recent studies have demonstrated the ability of some strains to survive for several months in soil, sediments and sand in tropical and temperate environments (Anderson et al., 2005; Ishii et al., 2007). In freshwater, E. coli was found to persist up to 260 days in sterile river water (Flint, 1987), and between 270 days to more than 450 days in filtersterilized groundwater with varying nutrient composition (Cook and Bolster, 2007). E. coli cells in isolation chambers placed directly into streams and springs persisted in situ for up to four months (Davis et al., 2005).

Microorganism environmental fate models used as a framework for the establishment of Total Maximum Daily Limits (TMDLs) or Quantitative Microbial Risk Assessments (QMRAs) generally employ rudimentary descriptions of cell die-off kinetics and transport physics (Haas et al., 1999; Benham et al., 2006) but other models have also been described in the literature (Canale et al., 1993; Wilkinson et al., 1995; Kashefipour et al., 2002; Collins and Rutherford, 2004; Servais et al., 2007). The complexities of the processes that govern E. coli concentrations in surface waters complicate the prediction of the fate of microorganisms in natural systems, and therefore the capacity to predict fecal pollution impacts on human and animal health (Pachepsky et al., 2006). These assessments would be improved by a greater understanding of the ecology of $E$. coli in natural systems.

The primary purpose of this work was to examine if an indicator of "net persistence" of culturable E. coli in surface water samples was related to observed E. coli densities at the time of sampling. We enumerated by membrane filtration plate count $E$. coli populations in 232 water samples collected from the water column of rivers and streams within four river basins geographically dispersed within agriculturally dominated regions in Canada (Johnson et al., 2003; van Bochove et al., 2005; Smith et al., 2007; Wilkes et al., 2009). From these sampled waters, we defined a bulk indicator of $E$. coli persistence by determining the rate of change in these populations during a 24-h incubation under controlled laboratory conditions. In an attempt to establish the significance of this persistence indicator relative to other factors likely to impact directly $E$. coli densities in water courses (e.g., nutrients, temperature, water course size), we employed step-wise multiple regression to predict initial E. coli densities from the persistence indicator, and other environmental factors. Finally, we determined if water properties at the time of sampling were associated with $E$. coli persistence characteristics measured in the laboratory.

\section{Material and methods}

\section{Sample sites and surface water sampling}

Surface water sampling sites were located within four watersheds widely dispersed across Canada: the Bras d'Henri watershed in Québec (BDH; van Bochove et al., 2005), the South Nation River watershed in Ontario (SN; Wilkes et al., 2009), the Oldman River watershed in Alberta (OLD; Johnson et al., 2003), and the Sumas River watershed in British Columbia (SU; Smith et al., 2007). Water was sampled from 46 discrete locations $(5,23,12$, and 5 sampling sites in $\mathrm{BDH}, \mathrm{SN}, \mathrm{OLD}$, and $\mathrm{SU}$, respectively). Water samples $(N$ total $=232 ; 19,130,63$, and 20 samples from BDH, SN, OLD, and SU, respectively) were collected between May 28 and August 13, 2007 (Table 1). For bacterial analysis, one liter of surface water was collected at a depth of $0.5 \mathrm{~m}$ from the surface directly into sterile containers (Systems Plus, Woodstock, ON, 
Canada). For low water conditions, a water sample was retrieved halfway between the surface and the bottom. The samples (packed with cold packs) were shipped by overnight courier to Agriculture and Agri-Food Canada (AAFC) laboratories in London, ON, Canada.

\section{Weather and water physical and chemical quality}

Climate and water quality properties were determined for the SN, and not the other sites. Turbidity was measured using a Global Water WQ770 hand held unit of range 0-1000 nephelometric turbidity units (NTU) with an accuracy of $\pm 5 \%$ of scale (Global Water Instrumentation Inc., Gold River, CA). Solar radiation was recorded using a solar radiation sensor on a HOBO Weather Station Logger (Onset part \# H21-001, Onset Computer Corporation, Bourne, MA), with a $30 \mathrm{~min}$ interval, and were expressed in W.m ${ }^{-2}$. At time of sampling, water temperature, $\mathrm{pH}$, conductivity, dissolved oxygen and oxidation reduction potential were measured using a YSI 556 Multi Probe System unit with YSI sensor 5563 Probe module (Yellow Springs Instruments Inc., Yellow Springs, $\mathrm{OH}$ ), with accuracies of $\pm 0.15^{\circ} \mathrm{C}, \pm 0.2$ $\mathrm{pH}$ units, $\pm 0.001 \mathrm{mS} . \mathrm{cm}^{-1}, \pm 6 \%$ dissolved oxygen units, and $\pm 20 \mathrm{mV}$ (YSI 556 Multi Probe System Operations Manual). The YSI sensor(s) were suspended approximately $1 \mathrm{~m}$ below the surface of the water before reading, or if suspension of the sensor was not possible, in a retrieved bucket sample. For nutrient analysis, $1 \mathrm{~L}$ of water was taken from the sample site and refrigerated overnight at AAFC laboratories in Ottawa, Canada. On the following day, $300 \mathrm{~mL}$ of sample water was partitioned, stored in a cooler with icepacks, and delivered to the City of Ottawa, Robert O. Pickard Environmental Center (ROPEC) Laboratory for analysis of ammonia + ammonium and reactive phosphorus (Standard Methods 4500-NH3, and 4500-P), nitrite and nitrate (Standard Method 4110B), and total Kjeldahl nitrogen and total phosphorus (Standard Methods 4500-Norg and 4500-PF) (American Public Health Association, 1999). Rainfall, maximum, minimum and mean temperatures $\left({ }^{\circ} \mathrm{C}\right)$ for Russell Ontario were obtained from Environment Canada's Meteorological Service (Environment Canada, 2007). Variables summarising rainfall $(\mathrm{mm})$ on day of water sample, on day of water sample and one (Rain 1d), two (Rain 2d), three (Rain 3d) and seven (Rain 7d) days in advance were calculated. Mean temperature was expressed as the average of the maximum and minimum temperature on the day of sample collection. Strahler (1952) stream order for sample sites were calculated using a Geographic Information System and the Spatial Analyst package of ArcMap 9.1 (Environmental Systems Research Institute, Redlands, CA) and a digital elevation model (DEM). The DEM was "filled", removing small defects and/or sinks (areas of no outward flow), and flow direction and flow accumulation were calculated on the filled DEM, to determine the direction of flow on a cell by cell basis and the number of upstream cells contributing to a cell, in this case, the sampling locations. Stream thresholds were identified, and Strahler order was calculated using the "Stream Order" tool of the Spatial Analyst package.

\section{Escherichia coli enumeration and death rate determination}

Water samples were shipped on ice packs and received within $24 \mathrm{~h}$ of sampling by the microbiology laboratory. Water samples were enumerated for E. coli $\left(\mathrm{T} 0_{\mathrm{EC}}\right)$ by membrane filtration as described in Wilkes et al. (2009). Briefly, 10- to $100-\mathrm{mL}$ portions of water were filtered through sterile, 0.45 - $\mu \mathrm{m}$ pore-size, $47-\mathrm{mm}$-diameter cellulose acetate filters (Pall Gelman GN-6; VWR International, Mississauga, ON, Canada), and the filters were plated onto mFC basal medium (Difco, Fisher Scientific,

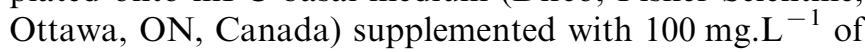
3-bromo-4-chloro-5-indolyl- $\beta$-D-glucopyranoside (BCIG) (hexylammonium salt; Inverness Medical, Ottawa, ON, Canada) and then incubated overnight at $44.5^{\circ} \mathrm{C}$. Samples were then placed in a $30^{\circ} \mathrm{C}$ incubator where they were held statically in the dark for $24 \mathrm{~h}$, following which culturable $E$. coli were again enumerated $\left(\mathrm{T} 24_{\mathrm{EC}}\right)$.

\section{Data analysis}

E. coli abundance was expressed in colony forming units (CFU). $100 \mathrm{~mL}^{-1}$. The change in abundance of culturable cells during the $30^{\circ} \mathrm{C}$ holding period is expressed as follows: $\Delta_{\mathrm{EC}}=\left[\left(\mathrm{T} 24_{\mathrm{EC}}-\mathrm{T} 0_{\mathrm{EC}}\right) / \mathrm{T} 0_{\mathrm{EC}}\right] \times 100$, where a value of -100 indicates a complete disappearance of cultivable $E$. coli, a value of 0 would indicate no change in abundance, and a value of 100 would indicate that $E$. coli abundance doubled during the 24-h holding period. Abundance variation values were compared using Wilcoxon matched-pairs test and the Mann-Whitney U test. The SPSS 11.0 for Windows program (SPSS, Inc., Chicago, IL) was used for all statistical analyses; all significance tests and correlations were considered significant statistically at a $p$ value of $\leq 0.05$. In some cases data were log transformed (base 10).

Main effects forward-based multiple stepwise regression analyses were conducted (Statistica, StatSoft Inc., Tulsa, OK) using data derived from the South Nation River watershed in Ontario. Maximum allowable tolerance settings (0.6) were used in order to maximally reduce variable contribution redundancy in the model. Two separate regression analyses were conducted. The first regression analyses was used to predict $\mathrm{T} 0_{\mathrm{EC}}$ from the persistence indicator $\left(\Delta_{\mathrm{EC}}\right)$ and a suite of water and weather variables that we hypothesized could be associated with the initial concentrations of E. coli (Table 2). The second analyses was designed to predict $\Delta_{\mathrm{EC}}$ from water quality properties of the sampled water in order to determine if there were distinct properties of the water that were predictive of the persistence of $E$. coli resulting from the incubation challenge. 
Table 2. Forward stepwise multiple linear regression (MLR) dependent and independent variables used for SN watershed samples.

\begin{tabular}{|c|c|c|c|c|c|}
\hline Variable & Unit & Description & $\begin{array}{l}\text { Log } \\
\text { transformed } \\
\text { for analysis } \\
\end{array}$ & $\begin{array}{l}\text { Used to } \\
\text { predict } \\
\mathrm{T} 0_{\mathrm{EC}} \\
\end{array}$ & $\begin{array}{c}\text { Used to } \\
\text { predict } \\
\Delta \mathrm{EC} \\
\end{array}$ \\
\hline$\overline{\Delta_{\mathrm{EC}}}$ & 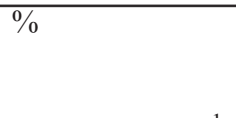 & $\begin{array}{l}\text { Percent change of } E \text {. coli concentration } \\
\text { as measured prior and post incubation } \\
\Delta_{\mathrm{EC}}=\left(\left[\mathrm{T} 24_{\mathrm{EC}}-\mathrm{T} 0_{\mathrm{EC}}\right] / \mathrm{T} 0_{\mathrm{EC}}\right)^{* 100}\end{array}$ & & $\mathrm{X}$ & \\
\hline $\mathrm{T} 0_{\mathrm{EC}}$ & CFU.100 mL ${ }^{-1}$ & E. coli concentration before incubation & $\mathrm{X}$ & & \\
\hline Water temperature & ${ }^{\circ} \mathrm{C}$ & $\begin{array}{l}\text { Temperature of water at time } \\
\text { of sample collection }\end{array}$ & & $\mathrm{X}$ & $\mathrm{X}$ \\
\hline $\mathrm{pH}$ & No unit & $\mathrm{pH}$ of water at time of sample collection & X & $\mathrm{X}$ & $\mathrm{X}$ \\
\hline Electrical conductivity (EC) & $\mathrm{mS} . \mathrm{cm}^{-1}$ & $\begin{array}{l}\text { Ability of water at time of sample collection } \\
\text { to conduct electrical current }\end{array}$ & $\mathrm{X}$ & $\mathrm{X}$ & $\mathrm{X}$ \\
\hline Dissolved oxygen (DO) & $\%$ & $\begin{array}{l}\text { Amount of gaseous } \mathrm{O}_{2} \text { dissolved in sample } \\
\text { water at time of collection }\end{array}$ & & $\mathrm{X}$ & $\mathrm{X}$ \\
\hline $\begin{array}{l}\text { Oxidation reduction } \\
\text { potential (ORP) }\end{array}$ & $\mathrm{mV}$ & $\begin{array}{l}\text { Potential of water to oxidize at time } \\
\text { of sample collection }\end{array}$ & $\mathrm{X}$ & $\mathrm{X}$ & $\mathrm{X}$ \\
\hline Turbidity & $\begin{array}{l}\text { NTU } \\
\text { (nephelometric } \\
\text { turbidity units) }\end{array}$ & $\begin{array}{l}\text { Cloudiness of sample water as measured } \\
\text { with a nephelometer sensor }\end{array}$ & $\mathrm{X}$ & $\mathrm{X}$ & $\mathrm{X}$ \\
\hline Strahler order & Numeric & $\begin{array}{l}\text { Ranges from } 1 \text { (first order) to } 7 \\
\text { (main branch of South Nation River). } \\
\text { See Strahler (1952) }\end{array}$ & & $\mathrm{X}$ & \\
\hline $\mathrm{NH}_{3}+\mathrm{NH}_{4}$ & $\mathrm{mg} . \mathrm{L}^{-1}$ & $\begin{array}{l}\text { Ammonia }+ \text { ammonium concentration } \\
\text { of sample water }\end{array}$ & $\mathrm{X}$ & $\mathrm{X}$ & $\mathrm{X}$ \\
\hline $\mathrm{NO}_{2}^{-}$ & $\mathrm{mg} \cdot \mathrm{L}^{-1}$ & Nitrite concentration in sample water & $\mathrm{X}$ & $\mathrm{X}$ & $\mathrm{X}$ \\
\hline $\mathrm{NO}_{3}^{-}$ & $\mathrm{mg} \cdot \mathrm{L}^{-1}$ & Nitrate concentration in sample water & $\mathrm{X}$ & $\mathrm{X}$ & $\mathrm{X}$ \\
\hline $\begin{array}{l}\text { Reactive phosphorus } \\
\text { (RP) }\end{array}$ & $\mathrm{mg} \cdot \mathrm{L}^{-1}$ & $\begin{array}{l}\text { Reactive phosphorus concentration } \\
\text { in sample water }\end{array}$ & $\mathrm{X}$ & $\mathrm{X}$ & $X$ \\
\hline $\begin{array}{l}\text { Total Kjeldahl } \\
\text { nitrogen }(\mathrm{TKN})\end{array}$ & $\mathrm{mg} . \mathrm{L}^{-1}$ & $\begin{array}{l}\text { Organic nitrogen concentration } \\
\text { in sample water }\end{array}$ & $\mathrm{X}$ & $\mathrm{X}$ & $\mathrm{X}$ \\
\hline Total phosphorus (TP) & $\mathrm{mg} . \mathrm{L}^{-1}$ & $\begin{array}{l}\text { Total phosphorus concentration } \\
\text { in sample water }\end{array}$ & $\mathrm{X}$ & $\mathrm{X}$ & $\mathrm{X}$ \\
\hline $\begin{array}{l}\text { Rainfall; Rain } 1_{\mathrm{d}} \text {; Rain } 2 \mathrm{~d}_{\mathrm{d}} \\
\text { Rain } 3_{\mathrm{d}} ; \text { Rain } 7_{\mathrm{d}}\end{array}$ & $\mathrm{mm}$ & $\begin{array}{l}\text { Total rainfall on day of sample } \\
\text { and } 1,2,3 \text { and } 7 \text { days in advance }\end{array}$ & & $\mathrm{X}$ & \\
\hline Max. temp. & ${ }^{\circ} \mathrm{C}$ & $\begin{array}{l}\text { Daily maximum air temperature } \\
\text { on day of sample }\end{array}$ & & $\mathrm{X}$ & \\
\hline Min. temp. & ${ }^{\circ} \mathrm{C}$ & $\begin{array}{l}\text { Daily minimum air temperature } \\
\text { on day of sample }\end{array}$ & & $\mathrm{X}$ & \\
\hline Mean temp. & ${ }^{\circ} \mathrm{C}$ & $\begin{array}{l}\text { Mean daily air temperature } \\
\text { on day of sample }\end{array}$ & & $\mathrm{X}$ & \\
\hline Insolation & MJ.m ${ }^{-2}$ & $\begin{array}{l}\text { Incoming solar radiation per day at } \\
\text { HOBO weather station in sample basin }\end{array}$ & & $\mathrm{X}$ & \\
\hline
\end{tabular}

\section{Results}

Initial culturable $E$. coli abundance in water samples $(N=232)$ ranged from undetectable $\left(<1\right.$ CFU.100 $\left.\mathrm{mL}^{-1}\right)$ to $1.7 \times 10^{3}$ CFU.100 $\mathrm{mL}^{-1}$ (average $\pm \mathrm{SD}$ of $1.7 \pm 2.6 \times$ $10^{2} \mathrm{CFU} 100 . \mathrm{mL}^{-1}$ ). After a 24 -h holding period at $30^{\circ} \mathrm{C}$, E. coli abundance was generally significantly reduced (Wilcoxon matched-pairs test, $p<0.0001$ ) and ranged between undetectable to $6.7 \times 10^{2}$ CFU.100 $\mathrm{mL}^{-1}$ (average $\pm \mathrm{SD}$ of $0.6 \pm 1.0 \times 10^{2} \quad$ CFU. $100 \mathrm{~mL}^{-1}$ ) (Table 1). Abundance decreased from $528 \pm 319$ to $114 \pm 154$ CFU. $100 \mathrm{~mL}^{-1}$ for BDH, from $282 \pm 700$ to $103 \pm 361$ CFU. $100 \mathrm{~mL}^{-1}$ for $\mathrm{SN}$, from $84 \pm 98$ to $34 \pm 37$ CFU.100 $\mathrm{mL}^{-1}$ for OLD, and from $332 \pm 486$ to $152 \pm 167 \mathrm{CFU} .100 \mathrm{~mL}^{-1}$ for $\mathrm{SU}$ over the incubation period (Table 1). Calculated $\Delta_{\mathrm{EC}}$ ranged between -100 and $413 \%$ with an average \pm SD of $-50 \pm 60 \%$. A total of 18 samples exhibited an increase in their $E$. coli densities after the incubation period (positive $\Delta_{\mathrm{EC}}$ values): nine of these samples had $\mathrm{T} 0_{\mathrm{EC}}$ densities below the 1 st quartile of the dataset, indicating that these high increases might be related to the reproducibility of the enumeration method when the E. coli concentrations are low. Sample $\Delta_{\mathrm{EC}}$ values were compared between ranges of initial $E$. coli abundance values $\left(\mathrm{T} 0_{\mathrm{EC}}\right)$ as defined based on quartile of the initial abundance distribution (group 1: $<20$ CFU.100 mL ${ }^{-1}, N=60$; group 2: 20-70.5 CFU.100 $\mathrm{mL}^{-1}$, $N=56$; group 3: 70.5-220 CFU.100 $\mathrm{mL}^{-1}, N=59$; and group 4: > 220 CFU.100 $\mathrm{mL}^{-1}, N=57$; with samples from the four watersheds parsing out evenly within all 


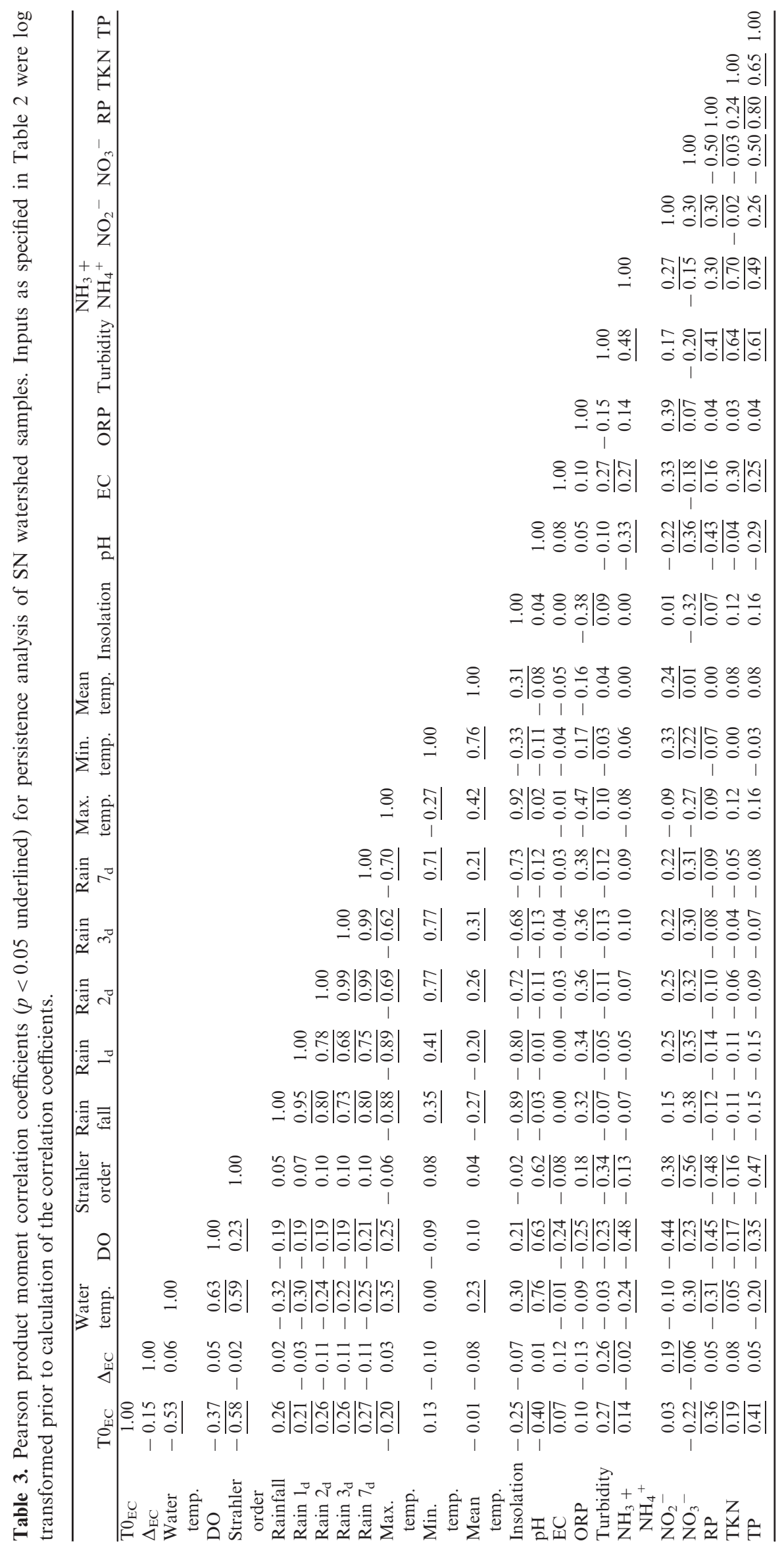


Table 4. Stepwise multiple regression results and coefficients using parameters described in Table 2, for SN watershed samples. Independent variables are listed in order of forward step model contribution. Bolded values are significant at 0.05 level.

\begin{tabular}{|c|c|c|c|c|c|c|}
\hline $\begin{array}{l}\text { Ind. variable or } \\
\text { intercept }\end{array}$ & Beta & Std. error of beta & B & Std. error of B & $p$-Level & Adjusted $\mathrm{R}^{2}$ \\
\hline \multicolumn{7}{|l|}{ Predicting $\mathrm{T} 0_{\mathrm{EC}}$} \\
\hline Intercept & & & 2.895232 & 0.170118 & 0.0000 & \\
\hline Strahler order & -0.522682 & 0.071253 & -0.208986 & 0.028489 & 0.0000 & 0.33 \\
\hline Rain 7 & 0.317954 & 0.063639 & 0.015749 & 0.003152 & 0.0000 & 0.43 \\
\hline Total phosph. & 0.197214 & 0.071196 & 0.446386 & 0.161149 & 0.0064 & 0.46 \\
\hline$\Delta_{\mathrm{EC}}$ & -0.132763 & 0.063368 & -0.002081 & 0.000993 & 0.0381 & 0.48 \\
\hline \multicolumn{7}{|l|}{ Predicting $\Delta_{\mathrm{EC}}$} \\
\hline Turbidity & 0.345710 & 0.094199 & 21.9649 & 5.98502 & 0.0003 & 0.06 \\
\hline $\mathrm{NH}_{3}+\mathrm{NH}_{4}$ & -0.194238 & 0.094458 & -15.0387 & 7.31335 & 0.0417 & 0.08 \\
\hline
\end{tabular}

density groups: $\chi^{2}$ test, $p=0.084$ ) (Fig. 1). Differences in $\Delta_{\mathrm{EC}}$ were observed between low and high abundance levels $\left(\Delta_{\mathrm{EC}}\right.$ average $\pm \mathrm{SD}$ of $-29 \pm 85 \%$ and $-64 \pm 23 \%$, for group 1 and 4 respectively; Mann-Whitney test, $p<0.05$ ). Between watersheds, E. coli abundance variations following holding period were significantly different between SN and SU, with culturable populations in SU samples being more persistent than those in $\mathrm{SN}$ samples $\left(\Delta_{\mathrm{EC}}\right.$ average \pm SD of $-29 \pm 49 \%$ and $-58 \pm 49 \%$, respectively; Mann-Whitney test, $p<0.001)$. No difference was observed between any of the other watersheds.

A multiple linear regression (MLR) analysis was carried out on SN samples as a case study: the correlation matrix among the variables listed in Table 2, indicated that logged-transformed $\mathrm{T} 0_{\mathrm{EC}}\left(\mathrm{T} 0_{\mathrm{EC}}\right.$ was initially not normally distributed) was significantly correlated at the 0.05 level with a wide variety of environmental and water quality properties (Table 3 ). Logged $\mathrm{T} 0_{\mathrm{EC}}$ was insignificantly $(p>0.05)$ but negatively correlated with $\Delta_{\mathrm{EC}}$. The persistence indicator $\left(\Delta_{\mathrm{EC}}\right)$ was found to be significantly correlated with only turbidity and $\mathrm{NO}_{2}{ }^{-}$concentration. The stepwise regression results for the $\mathrm{SN}$ data set are presented in Table 4 . Briefly, the model predicting $\mathrm{T} 0_{\mathrm{EC}}$ from the independent variables given in Table 2 , indicated that stream order, total rainfall seven days in advance of sampling day, total phosphorus, and $\Delta_{\mathrm{EC}}$ (persistence indicator) were the most important and significant $(p<0.05)$ model contributors. For this model, the adjusted $\mathrm{R}^{2}$ was $0.48(p<0.000)$ with a standard error of the estimate of 0.545 . The variance reduction associated with $\Delta_{\text {EC }}$ was small, but significant $\left(0.02\right.$ of adjusted $\left.\mathrm{R}^{2}\right)$. The stepwise multiple regression model predicting $\Delta_{\mathrm{EC}}$ from the variables given in Table 2 , indicated that turbidity and $\mathrm{NH}_{3}+\mathrm{NH}_{4}^{+}$were the most important model contributors, but variance reductions by these variables were very small. The adjusted $\mathrm{R}^{2}$ of the model is $0.08(p<0.00)$ with a standard error of the estimate of 45.88 .

\section{Discussion}

The persistence indicator exhibited less variability and more negative values for the heavily $E$. coli contaminated

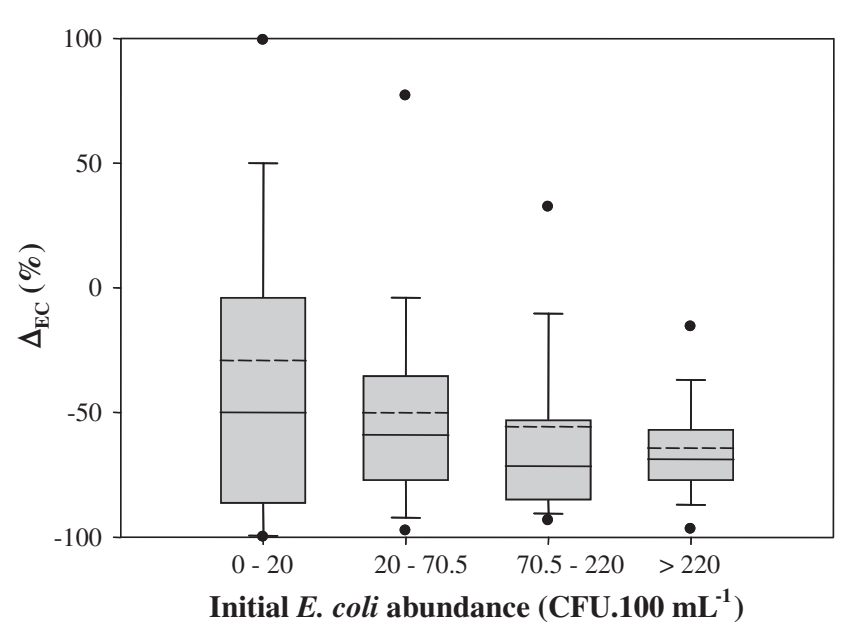

Fig. 1. Boxplots of $E$. coli persistence values $\left(\Delta_{\mathrm{EC}}, \%\right)$ during laboratory holding periods for four ranges of initial $E$. coli abundance $\left(0-20 ; 20-70.5 ; 70.5-220 ;>220\right.$ CFU.100 $\left.\mathrm{mL}^{-1}\right)$. Boxplots indicate the first and third quartile (bottom and top lines of the box), the median (middle line of the box) and the smallest and largest observations (bottom and top whiskers) of a data distribution. The outside dots indicate the 5th and the 95th percentile. The average value is indicated by the dashed line.

samples than in less heavily contaminated samples (Fig. 1). Furthermore, stepwise regression modelling with SN data found that $\mathrm{T} 0_{\mathrm{EC}}$ was linked statistically with the persistence indicator, suggesting that E. coli in water samples that were more heavily contaminated were less persistent than in water samples that were less heavily contaminated. We propose two possible reasons for these observations: recently some $E$. coli strains have been found to be environmentally adapted or naturalized, and shown to grow and maintain their populations in secondary habitats, soils, sediment, sand, or algal surfaces (Ishii and Sadowsky, 2008). In the present study, we speculate that heavily contaminated water samples could be fecally contaminated, and are characterized by isolates that survive poorly in secondary habitats. In contrast, $E$. coli populations detected in more pristine samples could be dominated by naturalized $E$. coli that survive relatively 
better in secondary habitats. Confirmation of this hypothesis would require that $E$. coli in the more pristine water samples be found to be distinct from those in the more heavily contaminated, using for example Multilocus Sequence Typing or Repetitive Extragenic Palindromic PCR (Ishii et al., 2006; Walk et al., 2007). A second possibility is that the $E$. coli concentrations in the range examined here did not saturate prey density with respect to (for example) planktonic grazing or viral lysis. The E. coli population density would then be rate limiting for the frequency of contact and efficiency of prey interception by grazers, or the production and availability of lytic viruses (Weinbauer and Höfle, 1998; Wommack and Colwell, 2000). Confirmation of this hypothesis would require a systematic analysis of grazing and bacteriophage-mediated lysis at varying E. coli densities.

The laboratory incubations (holding periods) reported here would capture some, but not all of the factors that are going to determine persistence in situ; yet, the incubations were devised to provide a standardized environment to gauge relative density changes. These would include biologically-mediated factors such as predation (McCambridge and McMeekin, 1980) and viral lysis (Carlucci and Pramer, 1960b); and water quality parameters including the presence of antibiotics or other inhibitors (Carlucci and Pramer, 1960a), organic and particulate matter (Bouteleux et al., 2005), and nutrients (Cook and Bolster, 2007). Laboratory incubations were carried out at $30^{\circ} \mathrm{C}$, which corresponded to the maximum water temperature recorded in the field during the sampling period (data not shown). Unlike most published persistence studies, we did not inoculate the water with defined concentrations of pure cultures, so our results would not be biased by the genetic characteristics of a given isolate, its physiological status according to how the inoculum was prepared, or by the initial cell density chosen.

Two key environmental variables that could influence persistence in situ that were absent in the in vitro incubations were incident radiation, and water temperature (Faust et al., 1975; Whitman et al., 2008). The relationship between these two parameters and the abundance of E. coli at time of sampling was evaluated in the SN and OLD datasets. There was little variability in the solar radiation during the sampling period (maximal daily irradiance average \pm SD: $786 \pm 248 \mathrm{~W} \cdot \mathrm{m}^{-2}$ ), and this could not account for the wide range in density of culturable E. coli in the water (Table 1). Furthermore, the absence of a relationship between irradiance and $\Delta_{\mathrm{EC}}$ suggests that potential variation in sublethal irradiation damage prior to sampling did not compromise the cells during the in situ incubation (Muela et al., 2000). Water temperature increased gradually over the sampling period from 13 to $29^{\circ} \mathrm{C}$ in $\mathrm{SN}$ and from 8 to $25^{\circ} \mathrm{C}$ in OLD. E. coli survival was shown to be negatively linked to temperature ranges between 10 and $30^{\circ} \mathrm{C}$ in various environments (Faust et al., 1975; Servais et al., 1985; Craig et al., 2004). However no evidence in the present work suggests that an increase in water temperature was linked to lower E. coli concentrations at sampling time, or beneficially influenced persistence during the holding period (Table 3).

E. coli abundance change $\left(\Delta_{\mathrm{EC}}\right)$ was most strongly correlated with turbidity, and turbidity provided the greatest contribution to variance reduction in the multiple regression modelling. The beneficial effect of turbidity on $E$. coli survival could be attributed to several mechanisms depending on the type of suspended particles. When suspended particles are of algal nature, it was found that $E$. coli cells can take advantage of the higher nutrient concentrations surrounding algal cells because of the release of organic substances (Brettar and Höfle, 1992). Particles can also represent ecological shelters against grazing pressure (Brettar and Höfle, 1992). Suspended solids such as sand, clay mineral or organic matter were also demonstrated to provide protection against UV light by limiting the depth of light penetration in the water column in estuarine or freshwater environments (Marshall, 1968; Craig et al., 2004; Beversdorf et al., 2007).

Stepwise regression modelling with $\mathrm{SN}$ data found that $\mathrm{T} 0_{\mathrm{EC}}$ was linked statistically, in order of model contribution, to stream order (a surrogate variable for dilution), rainfall for one week prior to sampling (a variable describing pollution driving mechanisms), total phosphorus (a parameter commonly correlated with fecal pollution due to runoff), and the persistence indicator $\left(\Delta_{\mathrm{EC}}\right)$; the latter suggesting that $E$. coli in water samples that were more heavily contaminated were less persistent than in water samples that were less heavily contaminated. Overall, based on the presented dataset collected on the $\mathrm{SN}$ watershed, these results indicate that when developing models predicting levels of E. coli contamination, in order of importance, dilution, climate drivers, and conditions influencing persistence of culturable cells are factors that need to be considered.

In summary, an indicator of $E$. coli persistence was poorly, but inversely related to initial $E$. coli concentrations in water from a variety of watersheds across Canada. For a subset of data obtained from one watershed, the indicator was a significant $(p<0.05)$ contributor to a multiple regression model predicting $E$. coli concentrations. The work presented here concerned flowing systems, and we would anticipate that the characteristics of persistence and growth of E. coli in lentic environments, stagnant drainage, lakes, or reservoirs, will undoubtedly differ from our observations. Overall, based on these results, we would suggest that the persistence factor is less important than dilution in describing $E$. coli densities, followed by factors that influence the loading of $E$. coli into watersheds (Roser et al., 2006). With respect to environmental fate models used for TMDL determinations or QMRAs, these results provide interesting insights that should improve the prediction of $E$. coli concentrations in natural systems and in surface waters, and should be helpful for prediction of fecal pollution impacts on human and animal health. 
Acknowledgements. This study was funded in part by the AAFC Agricultural Policy Framework National Water Quality Surveillance Research Initiative and the National AgriEnvironmental Standards Research Initiative. We thank T. Curtis and B. Beasley of AAFC Lethbridge and R. Walker of Alberta Environment for OLD water sample collection. M. Dumouchelle and S. Verhoeven provided excellent technical assistance.

\section{References}

American Public Health Association, 1999. Standard methods for the examination of water and wastewater, 20th edn., Clesceri L.S, Greenberg A.E and Eaton A.D. (eds.), American Public Health Association, Washington, DC.

Anderson K.L., Whitlock J.E. and Harwood V.J., 2005. Persistence and differential survival of fecal indicator bacteria in subtropical waters and sediments. Appl. Environ. Microbiol., 71, 3041-3048.

Benham B.L., Baffaut C., Zeckoski R.W., Mankin K.R., Pachepsky Y.A., Sadeghi A.M., Brannan K.M., Soupir M.L. and Habersack M.J., 2006. Modeling bacteria fate and transport in watersheds to support TMDLs. T. ASABE, 49, 987-1002.

Beversdorf L.J., Bornstein-Forst S.M. and McLellan S.L., 2007. The potential for beach sand to serve as a reservoir for Escherichia coli and the physical influences on cell die-off. J. Appl. Microbiol., 102, 1372-1381.

Bouteleux C., Saby S., Tozza D., Cavard J., Lahoussine V., Hartemann P. and Mathieu L., 2005. Escherichia coli behavior in the presence of organic matter released by algae exposed to water treatment chemicals. Appl. Environ. Microbiol., 71, 734-740.

Brettar I. and Höfle M.G., 1992. Influence of ecosystematic factors on survival of Escherichia coli after large-scale release into lake water mesocosms. Appl. Environ. Microbiol., 58, 2201-2210.

Canale R.P., Auer M.T., Owens E.M., Heidtke T.M. and Effler S.W., 1993. Modeling fecal-coliform bacteria. 2. Model development and application. Water Res., 27, 703-714.

Carlucci A.F. and Pramer P., 1960a. An evaluation of factors affecting the survival of Escherichia coli in sea water: III. Antibiotics. Appl. Environ. Microbiol., 8, 251-254.

Carlucci A.F. and Pramer P., 1960b. An evaluation of factors affecting the survival of Escherichia coli in sea water: IV. Bacteriophages. Appl. Environ. Microbiol., 8, 254-256.

Collins R. and Rutherford K., 2004. Modelling bacterial water quality in streams draining pastoral land. Water Res., 38, 700-712.

Cook K.L. and Bolster C.H., 2007. Survival of Campylobacter jejuni and Escherichia coli in groundwater during prolonged starvation at low temperatures. J. Appl. Microbiol., 103, 573-583.

Craig D.L., Fallowfield H.J. and Cromar N.J., 2004. Use of microcosms to determine persistence of Escherichia coli in recreational coastal water and sediment and validation with in situ measurements. J. Appl. Microbiol., 96, 922-930.

Davis R.K., Hamilton S. and Van Brahana J., 2005. Escherichia coli survival in mantled karst springs and streams, northwest Arkansas Ozarks, USA. J. Am. Water Resour. Assoc., 41, 1279-1287.
Dufour A.P., 1984. EPA health effects criteria for fresh recreational waters, United States Environmental Protection Agency, Research Triangle Park, NC.

Environment Canada, 2007. National climate data and information archive, Environment Canada, Ottawa, ON.

Faust M.A., Aotaky A.E. and Hargadon M.T., 1975. Effect of physical parameters on the in situ survival of Escherichia coli MC 6 in an estuarine environment. J. Appl. Microbiol., 30, 800-806.

Flint K.P., 1987. The long-term survival of Escherichia coli in river water. J. Appl. Bacteriol., 63, 261-270.

Haas C.N., Rose J.B. and Gerba C.P., 1999. Quantitative Microbial Risk Assessment, John Wiley and Sons, Inc., New York, NY.

Ishii S. and Sadowsky M.J., 2008. Escherichia coli in the environment: implications for water quality and human health. Microbes Environ., 23, 101-108.

Ishii S., Ksoll W.B., Hicks R.E. and Sadowsky M.J., 2006. Presence and growth of naturalized Escherichia coli in temperate soils from Lake Superior watersheds. Appl. Environ. Microbiol., 72, 612-621.

Ishii S., Hansen D.L., Hicks R.E. and Sadowsky M.J., 2007. Beach sand and sediments are temporal sinks and sources of Escherichia coli in Lake Superior. Environ. Sci. Technol., 41, 2203-2209.

Johnson J.Y.M., Thomas J.E., Graham T.A., Townshend I., Byrne J., Selinger L.B. and Gannon V.P.J., 2003. Prevalence of Escherichia coli O157:H7 and Salmonella spp. in surface waters of southern Alberta and its relation to manure source. Can. J. Microbiol., 49, 326-335.

Kashefipour S.M., Lin B. and Falconer R.A., 2002. Dynamic modelling of bacterial concentrations in coastal waters: effects of solar radiation on decay. Adv. Hydraul. Water Eng., 1-2, 993-998.

Leclerc H., Mossel D.A.A., Edberg S.C. and Struijk C.B., 2001. Advances in the bacteriology of the coliform group: their suitability as markers of microbial water safety. Annu. Rev. Microbiol., 55, 201-234.

Marshall K.C., 1968. Interaction between colloidal montmorillonite and cells of Rhizobium species with different inorganic surfaces. Biochim. Biophys. Acta, 156, 179-186.

McCambridge J. and McMeekin T.A., 1980. Relative effects of bacterial and protozoan predators on survival of Escherichia coli in estuarine water samples. Appl. Environ. Microbiol., 40, 907-911.

Muela A., Garcia-Bringas J.M., Arana I. and Barcina I., 2000. The effect of simulated solar radiation on Escherichia coli: the relative roles of UV-B, UV-A, and photosynthetically active radiations. Microb. Ecol., 39, 65-71.

Noble R.T., Lee I.M. and Schiff K.C., 2004. Inactivation of indicator micro-organisms from various sources of faecal contamination in seawater and freshwater. J. Appl. Microbiol., 96, 464-472.

Pachepsky Y.A., Sadeghi A.M., Bradford S.A., Shelton D.R., Guber A.K. and Dao T., 2006. Transport and fate of manure-borne pathogens: modeling perspective. Agr. Water Manage., 86, 1-92.

Roser D.J., Davies C.M., Ashbolt N.J. and Morison P., 2006. Microbial exposure assessment of an urban recreational lake: a case study of the application of new risk-based guidelines. Water Sci. Technol., 54, 245252. 
Servais P., Billen G. and Rego J.V., 1985. Rate of bacterial mortality in aquatic environments. Appl. Environ. Microbiol., 49, 1448-1454.

Servais P., Garcia-Armisen T., George I. and Billen G., 2007. Fecal bacteria in the rivers of the Seine drainage network (France): sources, fate and modelling. Sci. Total Environ., $375,152-167$.

Smith I.M., Hall K.J., Lavkulich L.M. and Schreier H., 2007. Trace metal concentrations in an intensive agricultural watershed in British Columbia, Canada. J. Am. Water Resour. Assoc., 43, 1455-1467.

Strahler A.N., 1952. Hypsometric (area altitude) analysis of erosional topology. Geol. Soc. Am. Bull., 63, 1117-1142.

Topp E., Welsh M., Tien Y.C., Dang A., Lazarovits G., Conn K. and Zhu H., 2003. Strain-dependent variability in growth and survival of Escherichia coli in agricultural soil. FEMS Microbiol. Ecol., 44, 303-308.

U.S. Environmental Protection Agency (USEPA), 2000. Improved enumeration methods for the recreational water quality indicators: Enterococci and Escherichia coli, Office of Science and Technology, Washington, DC.

van Bochove E., Dechmi F., Nolin M.C., Chantigny M.H., Lemieux C., Thériault G. and Corriveau J., 2005. Evaluation of beneficial agricultural management practices on water quality at edge-of-field and micro-watershed scales in Southern Québec, Canada. Proceedings of the International
Water Association, 9th Diffuse Pollution Conference, Johannesburg, South Africa.

Walk S.T., Alm E.W., Calhoun L.M., Mladonicky J.M. and Whittam T.S., 2007. Genetic diversity and population structure of Escherichia coli isolated from freshwater beaches. Environ. Microbiol., 9, 2274-2288.

Weinbauer M.G. and Höfle M.G., 1998. Significance of viral lysis and flagellate grazing as factors controlling bacterioplankton production in a eutrophic lake. Appl. Environ. Microbiol., 64, 431-438.

Whitman R.L., Przybyla-Kelly K., Shively D.A., Nevers M.B. and Byappanahalli M.N., 2008. Sunlight, season, snowmelt, storm, and source affect $E$. coli populations in an artificially ponded stream. Sci. Total Environ., 390, 448-455.

Wilkes G., Edge T., Gannon V., Jokinen C., Lyautey E., Medeiros D., Neumann N., Ruecker N., Topp E. and Lapen D.R., 2009. Seasonal relationships among indicator bacteria, pathogenic bacteria, Cryptosporidium oocysts, and Giardia cysts in surface waters within an agricultural landscape. Water Res., 43, 2209-2223.

Wilkinson J., Jenkins A., Wyer M. and Kay D., 1995. Modeling fecal-coliform dynamics in streams and rivers. Water Res., $29,847-855$.

Wommack K.E. and Colwell R.T., 2000. Virioplankton: viruses in aquatic ecosystems. Microbiol. Mol. Biol. Rev., 64, 69-114. 